\title{
Polarographic Behavior of Iodide and Its Mercury and Cadmium Compounds in Acetone
}

\author{
Hitoshi MORI*, Tomihito Kambara** and Masao SugawarA**
}

\begin{abstract}
The polarographic behavior of iodide ion, its mercury compounds and tetraiodocadmate(II) ion have been investigated in acetone containing the supporting electrolyte of $0.1 \mathrm{M}$ sodium perchlorate. Iodide ion produces two anodic waves, the first step of which is due to the oxidation of mercury to form triiodomercurate(II) ion $\mathrm{HgI}_{3}{ }^{-}$and the second step to form mercury iodide $\mathrm{HgI}_{2}$. The tetraiodocadmate(II) ion produces a cathodic wave and three anodic waves, all of which are reversible process. The cathodic wave is ascribed to the reduction of cadmium(II)-iodide complex. The first and third anodic waves are identical to those of iodide ion. The second anodic step is ascribed to the electrode process : $3 \mathrm{CdI}_{2}+2 \mathrm{Hg}-4 \mathrm{e} \rightleftharpoons 2 \mathrm{HgI}_{3}{ }^{-}+3 \mathrm{Cd}^{2+}$.
\end{abstract}

\section{Introduction}

It is well known that the anion forming stable complex with mercury ion facilitates anodic dissolution of the mercury electrode. The halogen-halide systems have been studied by means of voltammetry in non-aqueous solvent such as dimethylformamide $(\mathrm{DMF})^{1 \sim 3)}$, acetonitrile (AN $)^{4 \sim 6)}$, dimethylsulfoxide (DM$\mathrm{SO})^{7)}$, acetic anhydride ${ }^{8)}$, acetic acid ${ }^{8 \gamma}$, pyrrolidone- $2^{91}, \mathrm{~N}$-methylpyrrolidone ${ }^{10)}$ and tetrahydrofuran ${ }^{11}$. The electrode reaction of halide ions at the dropping mercury electrode has been reported by Matsui et al. ${ }^{3,12)}$. Polarographic reduction of metal-halide compounds have also been studied in different non-aqueous solvents ${ }^{13 \sim 15}$. However, only small set of data $^{16,17)}$ on the anodic process of metal-halide complex in non-aqueous media is available.

In the present work, polarographic behavior of iodide and tetraethylammonium tetraiodocadmate (II) $\left\{\left(\mathrm{Et}_{4} \mathrm{~N}\right)_{2}\left(\mathrm{CdI}_{4}{ }^{2-}\right)\right\}$ in acetone are investigated. Acetone has been recommended as a solvent for anodic polarography of alkylxanthate ion $^{18)}$.

\section{Experimental}

The electrolysis cell was assembled as described by Misumi and Aihara ${ }^{15)}$, except that twe electrode system was employed. Polarograms were recorded with a Yanagimoto polar-

\footnotetext{
* Present address : Ohtsuka Pharnaceutical Co. (Naruto)

** Department of Chemistry, Faculty of Science, Hokkaido University (Sapporo 060)

Key Words: Anodic Polarography, Acetone, Iodide Ion, Iodocomplexes, Mercury (II), Cadmium (II)
}

ograph PA-102. The dropping mercury electrode has the following characteristics: $m=$ $1.058 \mathrm{mg} \mathrm{s}^{-1}$ and $t=6.32 \mathrm{~s}$ at open circuit in an acetone solution of $0.1 \mathrm{M}$ sodium perchlorate when $h=50 \mathrm{~cm}$. There ference electrode was an aqueous $\mathrm{SCE}$ with an agar salt bridge of $0.1 \mathrm{M}$ sodium perchlorate. After polarograms were recorded at $16 \pm 0.1^{\circ} \mathrm{C}$, conductivity of the electrolysis solution was measured with a TOA conductometer, model $\mathrm{CM}-2 \mathrm{~A}$, in order to correct potentials for the $\mathrm{iR}$ drop ${ }^{19)}$. Liquid junction potential was found to be almost constant through all of measurements as evaluated employing aqueous SCE and acetone saturated calomel electrode ${ }^{20)}$. Therefore, potentials were corrected only for the iR drop. The clcctrolysis solution was deaerated by introducing nitrogen which passed through two traps containing acetone and Drilite (anhydrous calcium sulfate), respectively.

Acetone (Kanto Chemicals Co., extra pure grade) was purified according to Coetzee and Siano ${ }^{21)}$ and stored in a desiccator with silica gel. Commercially available tetraethylammonium iodide $\left(\mathrm{Et}_{4} \mathrm{NI}\right)$ and mercury iodide $\left(\mathrm{HgI}_{2}\right)$ were recrystallized from ethanol-water mixture. Preparation of tetraethylammonium triiodomercurate (II) $\left\{\mathrm{Et}_{4} \mathrm{~N}^{+} \mathrm{HgI}_{3}^{-}\right\}$was similar to that of tetraethylammonium tribromomercurate $(\text { II })^{3)}$. The yellow precipitate obtained was recrystallized from DMF-ethanol solution. Cadmium perchlorate was prepared from cadmium nitrate by the method using cation exchange resin Dowex 50-X 8 (50-100 mesh) and the evaporation was carried out under reduced pressure at 
$60^{\circ} \mathrm{C}$. Cadmium perchlorate thus obtained was dried in vacuum at $60^{\circ} \mathrm{C}$ for a week ${ }^{15}$. The acetone solution of cadmium (II) perchlorate was standardized by EDTA titration. Tetraethylammonium tetraiodocadmate (II) $\left(\left(\mathrm{Et}_{1} \mathrm{~N}^{+}\right)_{2}-\right.$ $\left.\left(\mathrm{CdI}_{4}{ }^{2-}\right)\right\}$ was prepared by the following procedure. Potassium iodide $(10.5 \mathrm{~g})$ and cadmium nitrate hexahydrate $(2.0 \mathrm{~g})$ were added to 50 $\mathrm{cm}^{3}$ of water and agitated until they were in solution. The solution was added to $90 \mathrm{~cm}^{3}$ of aqueous solution containing $1.5 \mathrm{~g}$ of $\mathrm{Et}_{4} \mathrm{NI}$. The precipitate obtained was collected by filtration, washed with water and recrystallized from acetone-water. Found : Cd 12.63\%, I 56.39 \%6. Calculated for $\left[\left(\mathrm{C}_{2} \mathrm{H}_{5}\right)_{4} \mathrm{~N}\right]_{2} \mathrm{CdI}_{4}: \mathrm{Cd} 12.77 \%$, I $57.65 \%$. Sodium perchlorate used as supporting electrolyte was dried in vacuum at $60^{\circ} \mathrm{C}$ for $6 \mathrm{~h}$. All of glass wares and materials were kept in a desiccator with silica gel or sulfuric acid.

\section{Results and Discussion}

\subsection{Polarographic behavior of iodide ion} and its mercury compounds

Anodic polarogram of iodide ion in acetone

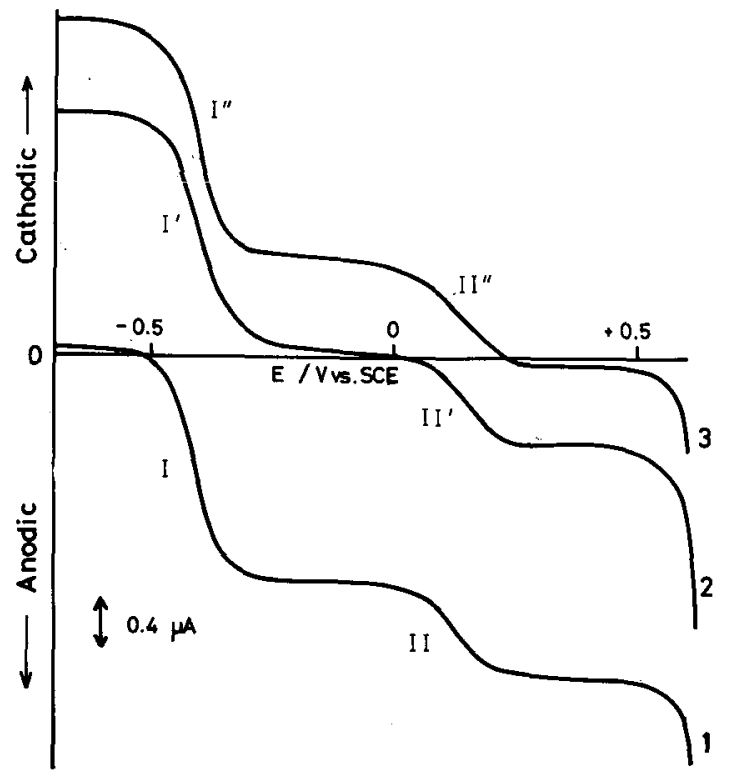

Fig. 1 Polarograms of (1) $0.6 \mathrm{mM}$ iodide ion, (2) $0.2 \mathrm{mM}$ triiodomercurate(II) ion and (3) $0.3 \mathrm{mM} \mathrm{HgI}_{2}$ in acetone containing $0.1 \mathrm{M}$ sodium perchlorate

Potentials were not corrected for the iR drop containing $0.1 \mathrm{M}$ sodium perchlorate as the supporting electrolyte is shown in Fig. 1. Two anodic waves are observed, half-wave potentials of which are -0.434 (step I) and -0.135 (step II) V vs. SCE, respectively, for $0.6 \mathrm{mM}$ iodide ion. The limiting current of steps I and II is proportional to the square root of mercury column height corrected for the back pressure. The relative temperature coefficient of wave height at $16^{\circ} \mathrm{C}$ is $1.10 \%$ for step I and $0.83 \%$ for step $\Pi$. The results indicate that both waves I and II are diffusion-controlled. The limiting current of steps I and II increases linearly with increasing concentratoin of iodide ion. The ratio $I_{\mathrm{d}}(\mathrm{I}) / I_{\mathrm{d}}$ (II) of diffusion current constants of steps $I$ and II, as tabulated in Table 1 , is approximately $2: 1$, suggesting that the number of electrons transferred at step I is twice as much as step II. With increasing concentration of iodide ion, the half-wave potential of step I shifts to a more negative value and that of step II to a more positive.

Electrode reaction of iodide ion in DMF has been reported by Misumi and Date ${ }^{3)}$. It may be assumed that the similar electrode process as in DMF proceeds also in acetone; namely, for the step I

Table 1 Polarographic data for iodide ion and its mercury compounds

\begin{tabular}{|c|c|c|c|c|c|}
\hline & \multirow{2}{*}{$\begin{array}{l}\text { Concentra- } \\
\text { tion }\end{array}$} & \multicolumn{2}{|c|}{$\begin{array}{l}\text { Half-wave } \\
\text { potentiala) }\end{array}$} & \multicolumn{2}{|c|}{$\begin{array}{l}\text { Diffusion current } \\
\text { constant }^{\text {b) }}\end{array}$} \\
\hline & & 1st wave & $\begin{array}{l}\text { 2nd } \\
\text { wave }\end{array}$ & 1st wave & $\begin{array}{l}\text { 2nd } \\
\text { wave }\end{array}$ \\
\hline \multirow{5}{*}{$\mathrm{Et}_{4} \mathrm{~N}^{+} \mathrm{I}^{-}$} & 0.4 & -0.421 & +0.129 & 1.86 & 0.81 \\
\hline & 0.6 & -0.434 & +0.135 & 1.95 & 0.88 \\
\hline & 0.8 & -0.440 & +0.138 & 2.00 & 0.95 \\
\hline & 1.0 & -0.445 & +0.140 & 1.97 & 0.91 \\
\hline & 1.2 & -0.455 & +0.143 & 2.03 & 0.92 \\
\hline \multirow{5}{*}{$\mathrm{Et}_{4} \mathrm{~N}^{+} \mathrm{HgI}_{3}{ }^{-}$} & 0.2 & -0.443 & +0.130 & 5.46 & 2.39 \\
\hline & 0.3 & -0.460 & +0.136 & 5.74 & 2.56 \\
\hline & 0.4 & -0.469 & +0.138 & 5.94 & 2.68 \\
\hline & 0.5 & -0.476 & +0.142 & 5.96 & 2.75 \\
\hline & 0.6 & -0.484 & +0.146 & 5.94 & 2.77 \\
\hline \multirow{5}{*}{$\mathrm{HgI}_{2}$} & 0.2 & +0.117 & -0.427 & 1.53 & 3.58 \\
\hline & 0.3 & +0.122 & -0.436 & 1.75 & 3.83 \\
\hline & 0.4 & +0.129 & -0.446 & 1.76 & 3.78 \\
\hline & 0.5 & +0.131 & -0.453 & 1.83 & 3.78 \\
\hline & 0.6 & +0.135 & -0.467 & 1.78 & 3.83 \\
\hline
\end{tabular}

a) $E_{1 / 2}$ vs. $\mathrm{SCE}$, corrected for iR drop

b) $I_{\mathrm{d}}=i_{\mathrm{a}} \mathrm{C}^{-1} \mathrm{~m}^{-2 / 8} t^{-1 / 6}$ 


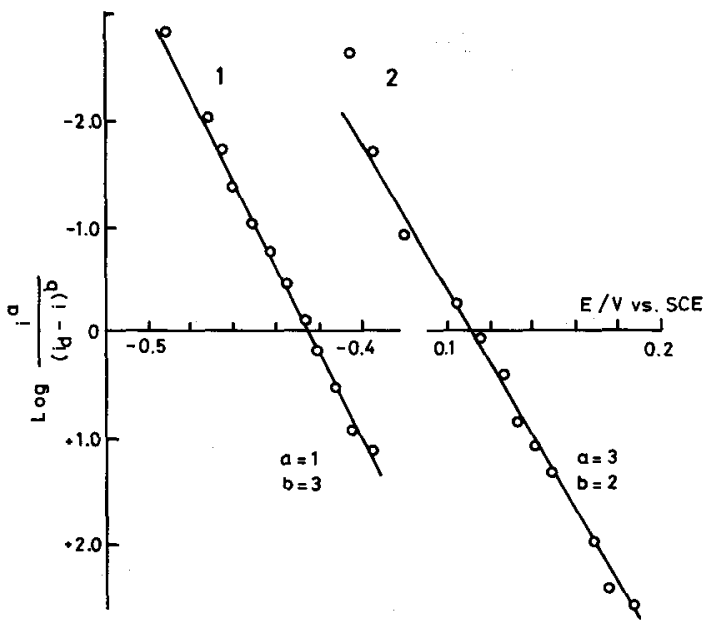

Fig. 2 A plot of $\log \left\{i^{\mathrm{a}} /\left(i_{\mathrm{d}}-i\right)^{\mathrm{b}}\right\}$ vs. $E$ at $16^{\circ} \mathrm{C}$ for $1.4 \mathrm{mM}$ iodide ion

(1) wave I, (2) wave II

$$
\mathrm{Hg}+3 \mathrm{I}^{-}-2 \mathrm{e} \rightleftarrows \mathrm{HgI}_{3}^{-}
$$

and for the step II

$$
2 \mathrm{HgI}_{3}{ }^{-}+\mathrm{Hg}-2 \mathrm{e} \rightleftarrows 3 \mathrm{HgI}_{2}
$$

The current-potential relationships of these electrode reactions are given by eqns. (3) and (4), respectively.

$$
\begin{aligned}
& E=E_{0}{ }^{\prime}+0.03 \log \frac{i}{\left(i_{\mathrm{d}}-i\right)^{3}} \\
& E=E_{0}{ }^{\prime \prime}+0.03 \log \frac{i^{3}}{\left(i_{\mathrm{d}}-i\right)^{2}}
\end{aligned}
$$

where $E_{0}^{\prime}$ and $E_{0}^{\prime \prime}$ are the formal standard potentials. The results of logarithmic analysis according to eqns. (3) and (4) are shown in Fig. 2. The plot has a slope of $27 \mathrm{mV}$ for step I and $30 \mathrm{mV}$ for step II, which are in agreement with the theoretical values.

The polarograms of mercury iodide complexes $\mathrm{HgI}_{3}^{--}$and $\mathrm{HgI}_{2}$ are also shown in Fig. 1. The $\mathrm{HgI}_{3}^{-}$ion gives a cathodic wave (step $\mathrm{I}^{\prime}$ ) and an anodic wave (step $\Pi^{\prime}$ ), and the $\mathrm{HgI}_{2}$ produces two cathodic waves (steps $I^{\prime \prime}$ and II"). The half-wave potentials of steps $I^{\prime}$ and $I^{\prime \prime}$ coincide with that of the anodic step $I$ of iodide ion and those of steps $\Pi^{\prime}$ and $I^{\prime \prime}$ with the step II of iodide ion, indicating the reversible electrode process. The diffusion current constants of the respective waves are given in Table 1. As the ratio of diffusion current constant, $I_{\mathrm{d}}(\mathrm{I}): I_{\mathrm{d}}\left(\mathrm{I}^{\prime}\right): I_{\mathrm{d}}\left(\mathrm{I}^{\prime \prime}\right)=1: 3: 2$ was found. The half-wave potentials of $\mathrm{HgI}_{3}{ }^{-}$and
$\mathrm{HgI}_{2}$ waves were plotted against the logarithm of their concentrations. The plot gives a straight line whose slope is in agreement with the theoretical value. Namely, we obtained -68 $\mathrm{mV}$ for step $\mathrm{I}^{\prime},+33 \mathrm{mV}$ for step $\mathrm{II}^{\prime},+33 \mathrm{mV}$ for step I" and $-69 \mathrm{mV}$ for step II". These results indicate that the electrode reaction of iodide ion in acetone follows the equs. (1) and (2).

\subsection{Polarographic behavior of cadmium (II)-iodide complex}

Polarograms of cadmium(II)-iodide system in acetone are shown in Fig. 3. The free cadmium (II) ion gives a cathodic wave at around $-0.35 \mathrm{~V}$. The limiting current diminishes when the concentration of iodide ion is increased, owing to the formation of cadmium (II)-iodide complexes which are reduced at a more negative potential. On the other hand, anodic waves IV and $\mathrm{V}$ appear at the concentration ratio of $\left[\mathrm{I}^{-}\right] /\left[\mathrm{Cd}^{2+}\right]=1,2$ and $3 . \mathrm{At}$ $\left[\mathrm{I}^{-}\right] /\left[\mathrm{Cd}^{2+}\right]=4$ and 5 , an additional anodic wave III appears. A polarogram of $0.2 \mathrm{mM}$ cadmium (II) salt $\left\{\left(\mathrm{Et}_{4} \mathrm{~N}^{+}\right)_{2}\left(\mathrm{CdI}_{4}{ }^{2-}\right)\right\}$ is identical to (5) in Fig. 3. Further experiments were carried out by using the cadmium (II) salt. The wave heights III, IV and V are proportional to the square root of mercury column height.

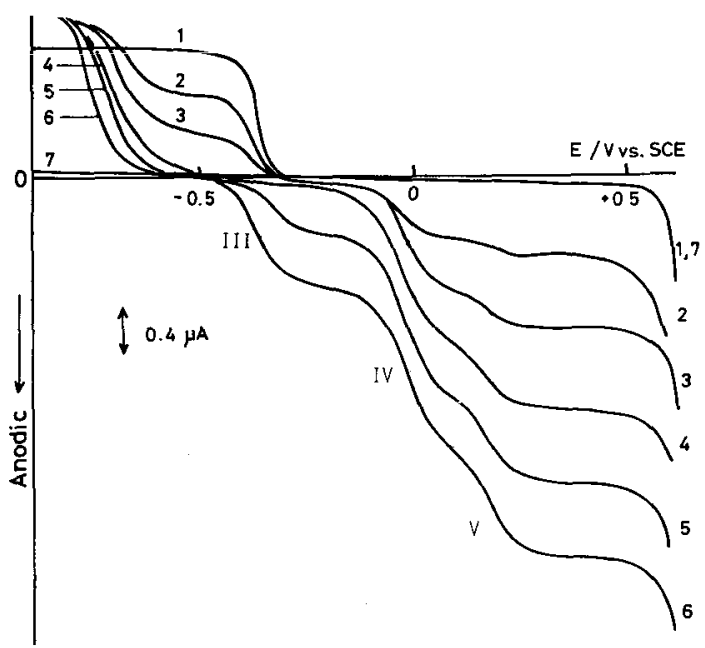

Fig. 3 Polarograms of cadmium (II)-iodide system

$[\mathrm{Cd}(\mathrm{II})]=0.2 \mathrm{mM}$. Concentration ratio : (1) $\left[\mathrm{I}^{-}\right] /$ $\left[\mathrm{Cd}^{2+}\right]=0,(2)=1,(3)=2,(4)=3,(5)=4,(6)=$ 5 , (7) Supporting electrolyte only $\left(0.1 \mathrm{M} \mathrm{NaClO}_{4}\right)$ 
Table 2 Polarographic data for tetraethyammonium tetraiodocadmate (II) $\left\{\left(\mathrm{Et}_{4} \mathrm{~N}^{+}\right)_{2}\left(\mathrm{CdI}_{4}{ }^{2-}\right)\right\}$

\begin{tabular}{c|c|c|c|c}
\hline \hline $\begin{array}{c}\text { Concentration } \\
\mathrm{mM}\end{array}$ & \multicolumn{3}{|c|}{ Diffusion current constant } \\
\cline { 2 - 5 } & $I_{\mathrm{d}}$ (cathodic) & $I_{\mathrm{d}}(\mathrm{III})$ & $I_{\mathrm{d}}(\mathrm{N})$ & $I_{\mathrm{d}}(\mathrm{V})$ \\
\hline 0.10 & 5.06 & 1.74 & 5.53 & 3.36 \\
0.15 & 4.88 & 1.75 & 5.65 & 3.33 \\
0.20 & 5.06 & 1.79 & 5.72 & 3.62 \\
0.30 & 4.81 & 1.70 & 5.50 & 3.78 \\
0.40 & 4.94 & 1.82 & 5.46 & 3.72 \\
0.55 & 4.83 & 1.78 & 5.36 & 3.55 \\
average & 4.93 & 1.76 & 5.54 & 3.56 \\
\hline
\end{tabular}

$I_{\mathrm{d}}$ (cathodic), $I_{\mathrm{d}}(\mathrm{III}), I_{\mathrm{d}}(\mathrm{IV})$ and $I_{\mathrm{d}}(\mathrm{V})$ are diffusion current constants of cathodic wave, wave III, wave IV and wave $\mathrm{V}$, respectively.

The relative temperature coefficient of limiting current at $16^{\circ} \mathrm{C}$ is $0.99 \%$ for the cathodic wave, $0.94 \%$ for the anodic wave III, $1.48 \%$ for wave $\mathrm{IV}$ and $1.10 \%$ for wave V. Since AC peaks corresponding to the respective DC steps are observed, the electrode reactions are reversible. The diffusion current constants of the waves III, IV and $V$ of the cadmium (II) salt were tabulated in Table 2. If the diffusion current constant of wave $\mathbb{I I}$ is regarded as 1 , the ratio $I_{\mathrm{d}}$ (cathodic) $: I_{\mathrm{d}}(\mathrm{III}): I_{\mathrm{d}}(\mathrm{IV}): I_{\mathrm{d}}(\mathrm{V})=2.8: 1$ :

$3.1: 2.1$ was found. Moreover, the half-wave potential of anodic wave III is in fairly good agreement with that of anodic step I of iodide ion and the wave $V$ with the step II.

Assuming that the tetraiodocadmate(II) ion $\mathrm{CdI}_{4}{ }^{2-}$ in acetone dissociates to liberate iodide ions according to

$$
\mathrm{CdI}_{4}{ }^{2-} \rightleftharpoons \mathrm{CdI}_{i}{ }^{(2-i)}+(4-i) \mathrm{I}^{-}
$$

the cathodic wave of the cadmium(II) salt may be attributed to the reduction of iodocomplexes of cadmium(II).

$$
\mathrm{CdI}_{i}{ }^{(2-1)}+\mathrm{Hg}+2 e \rightleftharpoons \mathrm{Cd}(\mathrm{Hg})+i \mathrm{I}^{-}
$$

where $i$ is the number of ligands bound to cadmium (II).

From a comparison of half-wave potentials of iodide and cadmium(II) salt and their diffusion current constants, it was thought that waves III and $V$ are identical to the step I and II of iodide ion, respectively. As shown in Fig. 4, the slope of a plot $E_{1 / 2}$ vs. $\log \left[\left(\mathrm{Et}_{4} \mathrm{~N}^{+}\right)_{2}\right.$ $\left.\left(\mathrm{CdI}_{4}{ }^{2}\right)\right]$ is $-54 \mathrm{mV}$ for wave III and $+30 \mathrm{mV}$ for wave $\mathrm{V}$, which are in good accordance with those expected from equs. (3) and (4). The results of logarithmic analysis, as shown in Fig. 5, indicate that the electrode reactions follow equs. (1) and (2), respectively.

For the anodic wave II, the following electrode reaction was assumed.

$$
\begin{aligned}
& m \mathrm{CdI}_{j}{ }^{2-j}+n \mathrm{Hg}-2 n \mathrm{e} \\
& \quad \rightleftharpoons m \mathrm{CdI}_{k}{ }^{2-k}+n \mathrm{HgI}_{3}{ }^{-}
\end{aligned}
$$

where $j$ and $k$ are the number of ligands coordinated to cadmium(II). The Nernst equation corresponding to equ. (7) is given by

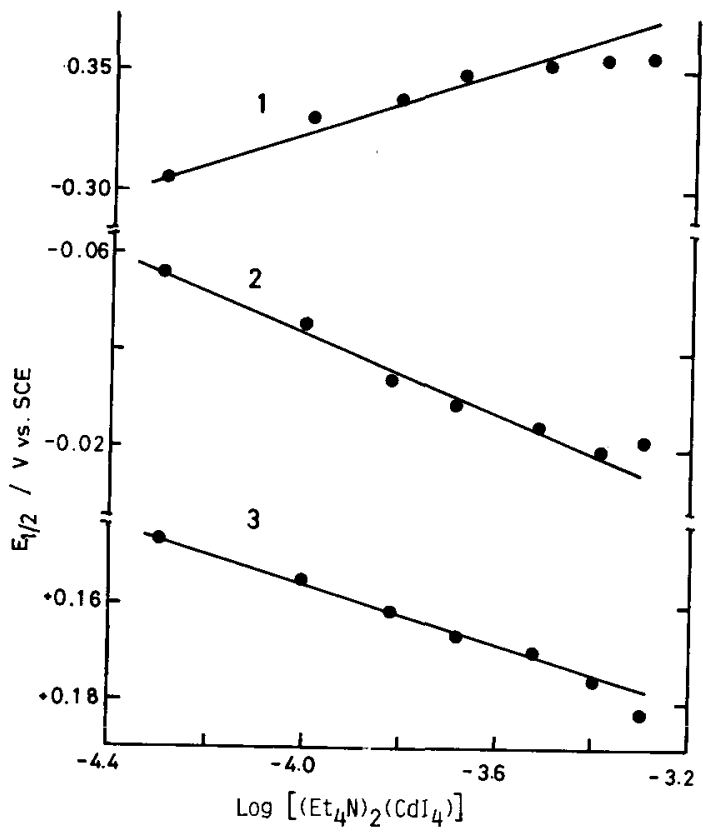

Fig. 4 A plot of $E_{1 / 2}$ vs. $\log \left[\left(\mathrm{Et}_{4} \mathrm{~N}^{+}\right)_{2}\left(\mathrm{CdI}_{4}{ }^{2-}\right)\right]$

(1) wave III, (2) wave $\mathrm{N}$, (3) wave $\mathrm{V}$

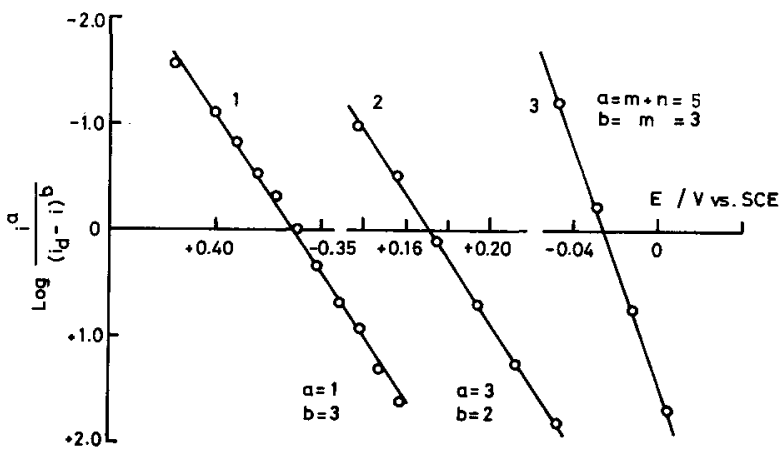

Fig. 5 A plot of $\log \left\{i^{\mathrm{a}} /\left(i_{\mathrm{d}}-i\right)^{\mathrm{b}}\right\}$ vs. $E$ at $16^{\circ} \mathrm{C}$ for (1) wave III, (2) wave $V$ and (3) wave $\mathrm{N}$ of $0.7 \mathrm{mM}\left\{\left(\mathrm{Et}_{4} \mathrm{~N}^{+}\right)_{2}\left(\mathrm{CdI}_{4}{ }^{2-}\right)\right\}$ 


$$
E=E_{0, \mathrm{a}}+\frac{0.03}{n} \log \frac{\left[\mathrm{CdI}_{k}^{2-k}\right]^{m}\left[\mathrm{HgI}_{3}^{-}\right]^{n}}{\left[\mathrm{CdI}_{j}^{2-j}\right]^{m}}
$$

The current-potential relationship is expressed as

$$
E=E_{0, \mathrm{a}}^{\prime}+\frac{0.03}{n} \log \frac{i^{m+n}}{\left(i_{\mathrm{d}}-i\right)^{m}}
$$

The half-wave potential $E_{1 / 2, a}$ is given by

$$
E_{1 / 2, \mathrm{a}}=E_{0, \mathrm{a}}^{\prime \prime}+0.03 \log i_{\mathrm{d}}
$$

A plot of $E_{1 / 2, \mathrm{a}}$ vs. $\log \left[\left(\mathrm{Et}_{4} \mathrm{~N}^{+}\right)_{2}\left(\mathrm{CdI}_{4}{ }^{2-}\right)\right]$ for wave IV is linear, as shown in Fig. 4, and has a slope of $+30 \mathrm{mV}$.

Logarithmic analysis was carried out for possible six cases in order to determine $m$ and $n$ values in equ. (9). When $m=3$ and $n=2$, assuming the equ. (11) or (12),

$$
\begin{aligned}
& 3 \mathrm{CdI}_{3}{ }^{-}+2 \mathrm{Hg}-4 \mathrm{e} \rightleftharpoons 2 \mathrm{HgI}_{3}{ }^{-}+3 \mathrm{CdI}^{+} \\
& 3 \mathrm{CdI}_{2}+2 \mathrm{Hg}-4 \mathrm{e} \rightleftharpoons 2 \mathrm{HgI}_{3}{ }^{-}+3 \mathrm{Cd}^{2+}
\end{aligned}
$$

the plot has a slope of $+15 \mathrm{mV}$, which is in agreement with the theoretical value (Fig. 5).

When $m=1$ and $n=1$, assuming the equation :

$$
\mathrm{CdI}_{3}{ }^{-}+\mathrm{Hg}-2 \mathrm{e} \rightleftharpoons \mathrm{HgI}_{3}{ }^{-}+\mathrm{Cd}^{2+}
$$

the slope was found to be $+49 \mathrm{mV}$, which does not agree with the theoretical value +30 $\mathrm{mV}$.

When $m=3$ and $n=1$, assuming the following three cases :

$$
\begin{aligned}
& 3 \mathrm{CdI}^{+}+\mathrm{Hg}-2 \mathrm{e} \rightleftharpoons \mathrm{HgI}_{3}{ }^{-}+3 \mathrm{Cd}^{2+} \\
& 3 \mathrm{CdI}_{2}+\mathrm{Hg}-2 \mathrm{e} \rightleftharpoons \mathrm{HgI}_{3}{ }^{-}+3 \mathrm{CdI}^{+} \\
& 3 \mathrm{CdI}_{3}{ }^{-}+\mathrm{Hg}-2 \mathrm{e} \rightleftharpoons \mathrm{HgI}_{3}{ }^{-}+3 \mathrm{CdI}_{2}
\end{aligned}
$$

The slope was $+23 \mathrm{mV}$, which is smaller than the theoretical one $+30 \mathrm{mV}$.

\section{3 Polarographic behavior of $\mathrm{Cd}^{2+}$ $\mathrm{HgI}_{3}{ }^{-}$and $\mathrm{Cd}^{2+}-\mathrm{HgI}_{2}$ systems}

Polarograms of the $\mathrm{HgI}_{3}{ }^{-}$ion in the presence of various amounts of cadmium(II) perchlorate are shown in Fig. 6. The wave height VII increases linearly with increasing concentration of $\operatorname{cadmium}(\mathrm{II})$ up to $3 \mathrm{mM}$, i.e., $\left[\mathrm{Cd}^{2+}\right] /$ $\left[\mathrm{HgI}_{3}^{-}\right]=3 / 2$ and above $3 \mathrm{mM}$ cadmium(II), it becomes constant, the wave VII appearing. The wave VII is ascribed to the reduction of cadmium (II)-iodide complex and the wave VII to the reduction of free cadmium(II) ion. The wave height VI increases with increasing concentration of cadmium(II) and becomes constant at above $\left[\mathrm{Cd}^{2+}\right] /\left[\mathrm{HgI}_{3}{ }^{-}\right]=3 / 2$. The anodic wave height $\Pi^{\prime}$ is independent of cadmium (II) concentration. The height of cathodic wave $\mathrm{I}^{\prime}$ of $\mathrm{HgI}_{3}^{-}$ion decreases linearly with increasing amount of cadmium (II) and it disappears completely at the ratio of $\left[\mathrm{Cd}^{2+}\right]$ / $\left[\mathrm{HgI}_{3}{ }^{-}\right]=3 / 2$. The results imply that the following electrode reaction may take place.

$$
3 \mathrm{Cd}^{2+}+2 \mathrm{HgI}_{3}^{-}+4 \mathrm{e} \rightleftharpoons 2 \mathrm{Hg}+3 \mathrm{CdI}_{2}
$$

The cadmium (II) complex $\mathrm{CdI}_{2}$ formed is further reduced at the potential of wave VII.

Figure 7 shows the polarograms of $\mathrm{Cd}^{2+}-\mathrm{HgI}_{2}$ system whose behavior are very similar to the $\mathrm{Cd}^{2+} \mathrm{HgI}_{3}^{-}$system. If the polarograms of

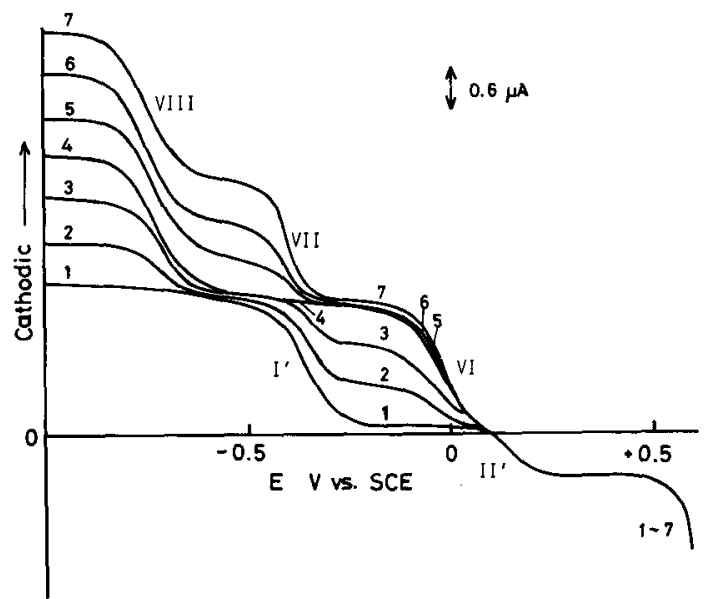

Fig. 6 Polarograms of $\mathrm{Cd}^{2+}-\mathrm{HgI}_{3}-$ system $\left[\mathrm{HgI}_{3}{ }^{-}\right]=0.2 \mathrm{mM}$. Concentration ratio : (1) $\left[\mathrm{Cd}^{2+}\right] /\left[\mathrm{HgI}_{s}{ }^{-}\right]$ $=0,(2)=1 / 2, \quad(3)=2 / 2,(4)=3 / 2, \quad(5)=4 / 2,(6)=5 / 2$ and $(7)=6 / 2$. Potentials were not corrected for $i R$ drop

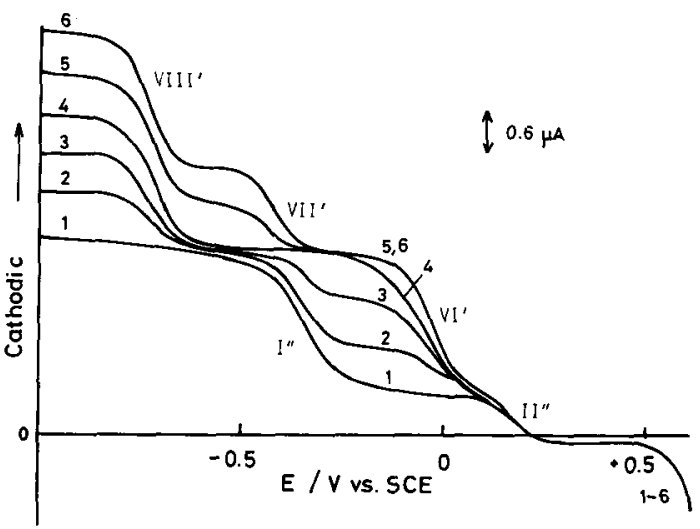

Fig. 7 Polarograms of $\mathrm{Cd}^{2+}-\mathrm{HgI}_{2}$ system $\left[\mathrm{HgI}_{2}\right]=0.3 \mathrm{mM}$. Concentration ratio : (1) $\left[\mathrm{Cd}^{2+}\right] /\left[\mathrm{HgI}_{2}\right]$ $=0,(2)=1 / 3,(3)=2 / 3,(4)=3 / 3,(5)=4 / 3$ and $(6)=5 / 3$. Potentials were not corrected for iR drop 
$\mathrm{Cd}^{2+}-\mathrm{HgI}_{2}$ system are shifted toward an anodic direction by about $0.6 \mu \mathrm{A}$, they overlap with those of $\mathrm{Cd}^{2+}-\mathrm{HgI}_{3}{ }^{-}$system at the equivalent concentration of cadmium (II), as might be expected from the equ. (2).

From the results described above, it is confirmed that the anodic process of wave $\mathrm{IV}$ of cadmium (II) salt $\left.\left(\mathrm{Et}_{4} \mathrm{~N}^{+}\right)_{2}\left(\mathrm{CdI}_{4}{ }^{2-}\right)\right\}$ is given by eqn. (12).

\section{References :}

1) C. Sinicki, P. Desportes, M. Bréant and R. Rosset, Bull. Soc. Chim. Fr. 829 (1968).

2) Yu. M. Povarov, I.E. Barbasheva and P.D. Lukovtsev, Elektrokhimiya 3, 1202 (1967).

3) Y. Matsui and Y. Date, Bull. Chem. Soc. Japan 41, 2913 (1968).

4) I.M. Kolthoff and J.F. Coetzee, J. Amer. Chem. Soc. 79, 1852 (1957).

5) A.I. Popov and D.H. Gesek, J. Amer. Chem. Soc. 80, 5346 (1958).

6) G. Dryhurst and P.J. Elving, Anal. Chem. 39, 606 (1967).

7) M. Michalmayr and D.T. Sawyer, J. Electroanal. Chem. 23, 387 (1969).
8) R. Guidelli and G. Piccardi, Anal. Lett. 1, 779 (1968).

9) C. Sinicki and M. Porteix, J. Electroanal. Chem. 34, 439 (1972).

10) M. Bréant, M. Bazouin, C. Buisson, M. Supin and J.M. Rebattu, Bull. Soc. Chim. Fr. 5065 (1968).

11) J. Perichon and R. Piccardi, Bull. Soc. Chim. Fr. 3707 (1967)

12) Y. Matsui, Y. Kurosaki and Y. Date, Bull. Chem. Soc. Japan 43, 1707 (1970).

13) K.H. Pool, J. Polaroy. Soc. 13, 23 (1967).

14) C. Furlani, L. Sestili, A. Ciana and F. Garbassi, Electrochim. Acta 15, 225 (1970).

15) S. Misumi and M. Aihara, Talanta 19, 549 (1972).

16) T. Ishii and T. Kambara, J. Electroanal. Chem. 88, 429 (1978).

17) G. Charlot, J. Badoz-Lambling and B. Trémillon, "Les Réactions Électrochimiques", Méthodes Électrochimiques d'analyse, Masson, Paris (1959).

18) A.M. Bond, A.T. Casey and J.R. Thacheray, $J$. Electroanal. Chem. 48, 71 (1973).

19) T. Fujinaga, K. Izutsu, K. Umemoto, T. Arai and T. Kataoka, Nippon Kagaku Kaishi 89, 105 (1968).

20) P. Arthur and H. Lyons, Anal. Chem. 24, 1422 (1952).

21) J.F. Coetzee and W. Siao, Inorg. Chem. 2, 14 (1963).

(Received Apr. 21, 1983; Accepted Aug. 31, 1983)

\section{SQ8会員のページ}

\section{文部省科学研究費エネルギー特別研究（エネルギー）「化学的エネルギーの研究班」 \\ 昭和 58 年度研究成果報告会}

\section{日 時 昭和 59 年 2 月 4 日 (土) 9 時加}

会 場 笹川記念会館 (東京都港区三田)

昭和 56 年度より 3 ヶ年計画で推進中の標記研究の 29 課題 (熱化学的・電気化学的エネルギー変換, エネルギー 材料) の本年度の成果報告会を行います. 会員の皆様と直接, 䦗接に関連したテーマも多くあります. 奮ってご参加 下さい，入場無料で約 150 ページの報告書を無料配布いたします．出席ご希望の力は葉書で下記までご連絡下さい。

連絡先 雪 240 横浜市保土ヶ谷区常盤台 156 横浜国立大学工学部エネルギー材料研究施設 高橋正雄（画045-335 -1451 内線 2969 2971) 